\section{Bola que balança a rede humana}

\section{Wagner Moreira}

Este poema foi publicado, sem título, na plaquete Pelada poética (Scriptum, 2006), organizada por Mário Alex Rosa e Welbert Belfort, e republicado no livro Pelada poética: antologia (Scriptum, 2013). Em 2014, o texto ganhou uma versão audiovisual e passou a integrar a exposição de longa duração do Museu do Mineirão - sala Futebol e outras Artes -, gravado em estúdio pelo próprio autor e sonorizado por Fabiano Fonseca, num encontro primoroso, que o elevou ao patamar que merecia: um dos mais bem acabados poemas de nossa literatura a dialogar com o futebol, tanto pela forma quanto pelo conteúdo.

"Bola que balança a rede humana" circula pelos espaços (e tempos) do campo de futebol e evoca enfaticamente a torcida que por sua vez senta, sorri, clama, reza, chama, verte, xinga, alça, dança, bota, chora, sobe, para, pula e canta esperança. Um poema circular, dionisíaco, rizomático. Uma grande homenagem ao jogo da bola - jogo da rede humana.

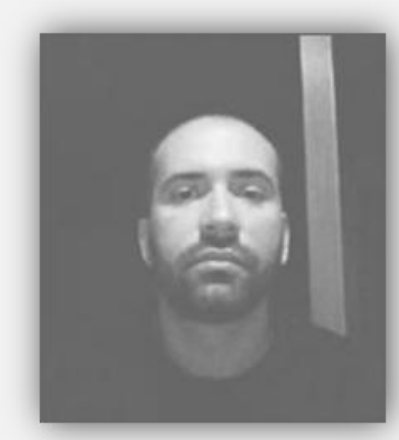

Wagner é graduado em Letras pela UFMG, com mestrado e doutorado em Literaturas de Língua Portuguesa pela PUC-Minas. É professor do CEFET-MG, atuando na graduação e pós-graduação do curso de Letras - Tecnologias da Edição.

Nasceu em Belo Horizonte, onde publicou os livros de poesia Eu não sou Vincent Willem van Gogh (edição do autor, 1998), selêemcio (edição do autor, 2002), transversos (Scriptum Livros, 2003), blues (SAC-Dazibao, 2004), experiência (Dezfaces, 2007), solo (Scriptum, 2015). 
o vento forte seco ácido em planos rizomáticos

balança as hastes flexíveis

nas direções possíveis

a torcida senta esperança

bola que balança a rede humana

o verde fofo cose flácido

espaços justapostos alinhados

em branco fixado geométrico

domínio exposto do que é atlético

a torcida sorri esperança

bola que balança a rede humana

o ferro firme oco duro

suspende enrijecido o branco

retângulo exposto vazado flanco

fenda entre o bom o mau futuro

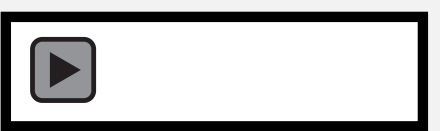

Para ouvir o áudio é necessário baixar este PDF ou acessar o link: http://bit.ly/FuLiA-UFMG-a-rede-humana. a torcida clama esperança

bola que balança a rede humana

o nó no extenso multiplica

as dobraduras do nylon

corda que sinuosa cria

janelas de amansar disparos

a torcida reza esperança

bola que balança a rede humana

cantos apontam o céu

marcam interseção limiar

brincam flamejantes

de centro circular

a torcida chama esperança

bola que balança a rede humana

outras flâmulas deslizam

adjacentes retilíneas

prontas para pararem

o que feito acidente

a torcida verte esperança

bola que balança a rede humana

o vento agudo fino fixa

tudo o que válido ou não

impera sobre o que evento

força posta pelo pulmão 
a torcida xinga esperança

bola que balança a rede humana

os uniformes concentrados frente a frente a cada lado

vibram energia pura

sangue em ponto de fervura

a torcida alça esperança

bola que balança a rede humana

a bola abala a barca da ventura

tresloucada em sanha oca

sinuosa existente no que dura

se desdobra ao largo do que toca

a torcida dança esperança

bola que balança a rede humana

nonada anda inventa gosto

faz mexe pensa executa

carece aragem enxuta

assisada instruída colosso

a torcida bota esperança

bola que balança a rede humana

carne sangue tento ação

borboleta em giro trivial regular

irremediável extenso danação

creio não creio viver triangular a torcida chora esperança

bola que balança a rede humana

rodeia quente estorvar

acontece travessia

tudo cabe aproximar

o instantâneo coisa

a torcida sobe esperança

bola que balança a rede humana

redemoinho no meio de si

matéria vertente zanzante

surgida imensidade a pedir desenho da volta flagrante

a torcida para esperança

bola que balança a rede humana

cabaça na cabeça folha seca

tabela chapéu volta drible de corpo

bicicleta pedalada de letra

rabo-de-vaca chute olímpico estrondo

a torcida pula esperança

bola que balança a rede humana

neuro esquizo psicótica

abraça o outro em si

a torcida canta esperança

bola que balança a rede humana. 